\title{
Odontoma localizado dentro del conducto dentario inferior: diagnóstico radiográfico y tratamiento quirúrgico de un caso clínico
}

\author{
Odontoma located within the inferior alveolar nerve: radiographic diagnosis \\ and surgical management of a clinical case
}

\author{
J. Vázquez Diego', C. Gandini Pablo², E. Carbajal Eduardo³
}

\begin{abstract}
Resumen: Se presenta un caso clínico de odontoma localizado dentro del conducto dentario inferior. El paciente de 54 años de edad es de sexo femenino. Se utiliza la técnica radiográfica panorámica para poder localizar y diagnosticar la afección. Posteriormente se realizó la intervención quirúrgica para extirpar la lesión y se realizó un seguimiento a corto y largo plazo para evaluar la recuperación de la sensibilidad de la zona afectada. El estudio histopatológico confirmó el diagnóstico de odontoma. Basado en lo expuesto se analiza al odontoma según ubicación, sexo y edad habiendo realizado una revisión de la literatura representada en tablas y gráficos.
\end{abstract}

Palabras clave: Odontoma; Técnica panorámica; Tratamiento quirúrgico; Conducto dentario inferior; Caso clínico.

Recibido: 27.03 .2008

Aceptado: 20.02.2009

\begin{abstract}
A clinical case of odontoma, located within the inferior dental nerve in a 54-year-old female patient, is reported. The lesion was situated and diagnosed by means of a conventional panoramic radiography technique. Then, a surgical approach was carried out to remove the pathological entity, and a short-and long-term follow-up control was done to evaluate sensitive recovery of the involved area. Later on, a histo-pathological study confirmed our previous diagnosis of odontoma. Based on our findings, odontoma is analyzed according to its location, sex and age of patients, as well as radiographic appearance. This analysis is presented through tables and graphics, after reviewing the scientific literature on this subject published over the last decade.
\end{abstract}

Key words: Odontoma; Panoramic technique; Surgical treatment; Inferior alveolar nerve.

1 Jefe de Trabajos Prácticos Regular. Cátedra de Radiología. Facultad de OdontologíaUniversidad de Buenos Aires. Argentina.

2 Ayudante de Primera Regular. Cátedra de Cirugía B. M. F. III. Facultad de

Odontología-Universidad de Buenos Aires. Argentina.

3 Profesor Adjunto Regular. Cátedra de Radiología.

Facultad de Odontología. Universidad de Buenos Aires. Argentina.

\section{Correspondencia:}

J. Vázquez Diego

Av. Corrientes $23622^{\circ}$ piso departamento " $\mathrm{C}$ "

C P 1046. Ciudad de Buenos Aires. Argentina

E- Mail: jv983@hotmail.com.ar 


\section{Introducción}

Los tumores odontogénicos benignos son neoplasias cuyo origen es a partir de tejidos dentales como la lámina dental, la papila dental ó el saco dentario.

El odontoma es el más frecuente de todos los tumores benignos de origen odontológico y según diferentes autores abarca desde el $51 \%$ hasta el $67 \%$. Esta neoplasia es una lesión de células odontogénicas epiteliales y mesenquimatosas, completamente diferenciadas y que forman esmalte, dentina y cemento. ${ }^{1-4}$

Se los clasifica en odontoma compuesto, complejo y fibro-odontoma ameloblástico. El compuesto es una malformación en la que están representados todos los tejidos dentarios con un patrón más ordenado que un odontoma complejo, de modo que la lesión consiste en muchas estructuras de aspecto dentario. La mayoría nos recuerda a los dientes de la dentición normal, pero en cada una el esmalte, la dentina, el cemento y la pulpa están dispuestos como en el diente normal. El complejo es una malformación en la que están representados todos los tejidos dentarios, en general bien formados individualmente pero dispuestos según un patrón más ó menos desordenado y el fibroodontoma ameloblástico es una neoplasia, con las características generales del fibroma ameloblástico, que contiene dentina y esmalte..$^{5-8}$

Las características clínicas del odontoma nos indican una mayor frecuencia del complejo por sobre el compuesto con un predominio del sexo masculino, la edad suele abarcar entre los 20 a 30 años y su ubicación suele ser en el odontoma compuesto el sector anterosuperior asociada a una pieza dentaria retenida y en el odontoma complejo el sector posteroinferior, es un tumor de crecimiento lento y asintomático, el tratamiento es quirúrgico a pesar que algunos autores recomiendan su seguimiento y una vez extirpado no suele recidivar. Histopatológicamente los odontomas compuestos presentan pulpa, dentina primaria y esmalte con menor calcificación a la de una estructura dentaria normal cemento primario y un trabeculado óseo entre los dentículos. Los odontomas complejos se caracterizan por dentina primaria, esmalte normal o menos calcificado, cemento inmaduro y una cápsula. ${ }^{9-13}$

Desde el punto radiográfico el odontoma compuesto presenta una imagen radiolúcida con múltiples radiopacidades que adoptan una configuración similar a dientes rodeados por banda radiolúcida asociado a un diente retenido o a un supernumerario. La imagen del odontoma complejo es de una masa radiopaca irregular, única o múltiple, con una banda radiolúcida rodeándola.

Se puede realizar un diagnóstico diferencial con el fibroma osificante, el fibroma calcificante o con un tumor odontogénico adenomatoideo. ${ }^{14-16}$ El objetivo de este trabajo es la presentación de un caso clínico de un odontoma localizado dentro del conducto dentario inferior a través del diagnóstico radiográfico, su tratamiento quirúrgico y realizar una revisión de la literatura científica.

\section{Caso Clínico}

Acude a la consulta un paciente de sexo femenino de 54 años, tras sufrir un estado inflamatorio agudo en el sector posterior izquier-
Odontogenic benign tumors are new growths that originate in dental tissues such as dental lamina, dental papilla or the dental sack. Odontoma is the most common kind of benign odontogenic tumor. According to various authors it is found in $51 \%$ to $67 \%$ of these cases. This tumor is a lesion of epithelial and mesenchymal odontogenic cells that are completely differentiated and from enamel, dentine and cement. . $^{-4}$

They are classified into 3 categories: compound odontoma, complex odontoma and ameloblastic fibro odontoma. Compound odontoma is a deformity in which all of the dental tissues are represented by a pattern that is more organized than that of the complex odontoma as a result the lesion is formed of many dental structures. The majority of the lesions don't look like a normal dentition, but in each one the enamel, dentine, cement and pulp are arranged like a normal tooth. Complex odontoma is a deformity in which all of the dental tissue is represented; in general it is individually well formed but arranged according to an unorganized pattern. The ameloblastic fibro-odontoma is a new growth that has the same general characteristics of ameloblast fibroma which contains dentine and enamel.5-8

Clinical characteristics indicate that complex odontoma is more frequent than compound odontoma and is predominately found in men between the ages of 20 and 30. Compound odontoma is usually located in the anterosuperior sector associated with a retained tooth while complex odontoma is usually located in the posteroineferior sector and is a slow growing, asymptomatic tumor. The treatment for this condition is surgical, although some authors recommend followup and once the tumor is removed it shouldn't recur.

Histopathologically, compound odontoma have less calcified pulp, primary dentine and enamel than the normal primary dental cement structure and as bone trabeculate between the denticles. Complex odontomas are characterized by primary dentine, normal or less calcified enamel, immature cement and a capsule. ${ }^{9-13}$

From a radiographic point of view, compound odontoma has a radio lucid image with many radiopacities that take on a configuration similar to that of the teeth surrounded by the radio lucid band associated with a retained tooth or a supernumerary tooth. . The image of the complex odontoma is one or many irregular radiopaque masses surrounded by a radio lucid band. A differential diagnostic can be carried out with the ossifying fibroma, the calcified fibroma or with an adenomatoid odontogenic tumor. ${ }^{14-16,19}$

The purpose of this study is to present localized odontoma inside the inferior alveolar nerve in a clinical case using a radiographic diagnostic, its surgical treatment and carry out a review of the scientific literature.

\section{Clinical Case}

A female patient age 54 attends a consult after suffering acute inflammation in the left posterior section of the 


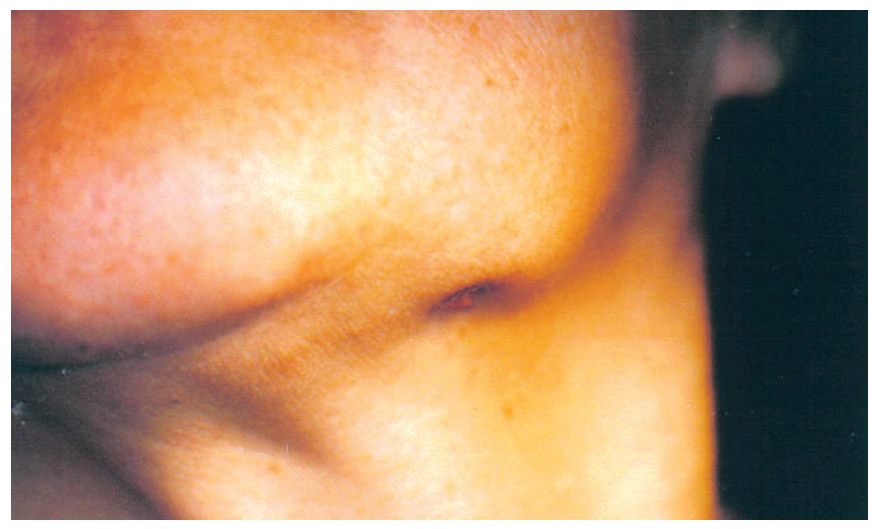

Figura 1. Se observa una inflamación localizada en el sector posteroinferior izquierdo.

Figure 1. A swelling can be observed in the postero-inferior region.

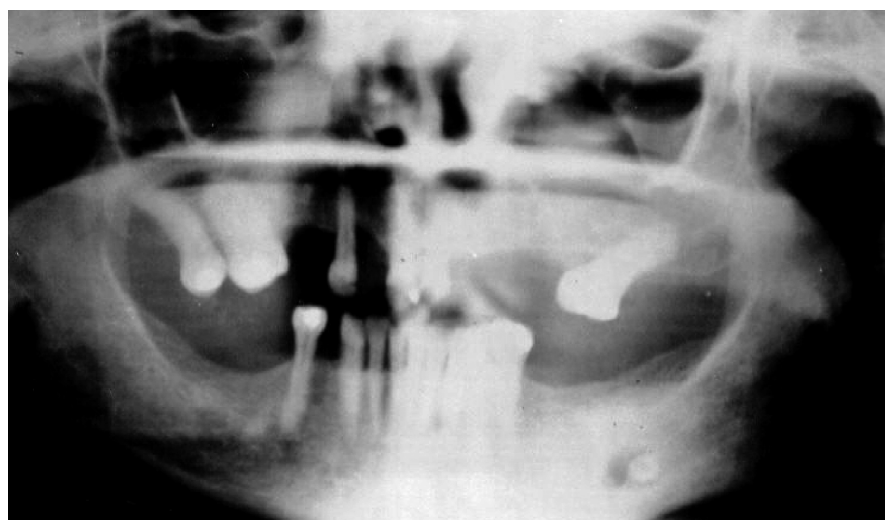

Figura 2. Radiografía panorámica: se visualiza una imagen radiopaca en el sector posteroinferior izquierdo, a la altura del conducto dentario inferior. Figure 2. A panoramic radiography shows a radio-opaque image in the postero-inferior region, at the level of the mandibular nerve.



Figura 3. Se observa la cavidad remanente, surcada de izquierda a derecha por el paquete vasculonervioso.

Figure 3. The remaining cavity is observed, with the neurovascular bundle passing through it from left to right.

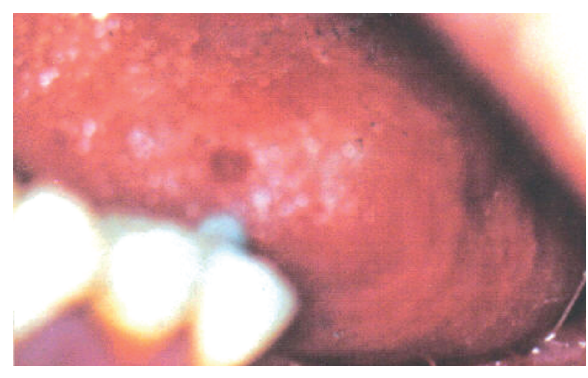

Figura 4. Se observa la sutura inmediata a la extirpación del fragmento.

Figure 4. It shows the suture placed immediately after extirpating the fragment.

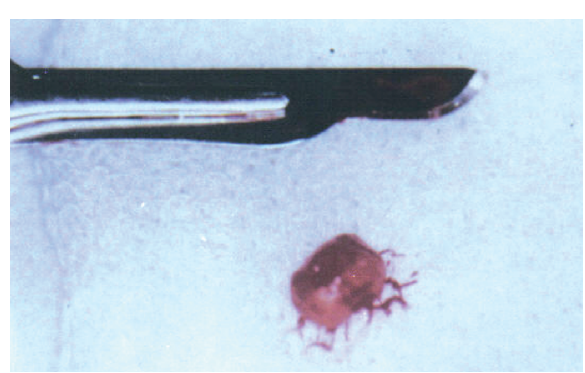

Figura 5. Imagen del material extraído Figure 5. An image of the removed material. do del maxilar inferior (Fig. 1). La paciente relata haber concurrido a un odontólogo hace un mes, recuerda que el mismo le realizó una toma radiográfica intraoral y le manifiestó no tener ninguna patología visible en dicha imagen dada la ausencia de las piezas.

Se realiza un minucioso estudio clínico observándose las ausencias de los molares inferiores del sector izquierdo y se observa un buen estado de salud bucodental. A partir de allí se decide realizar una radiografía extraoral panorámica con el objetivo de poder observar con mayor amplitud la zona en cuestión (Fig. 2).

En la radiografía se visualiza una imagen radiopaca, de forma redondeada y límites netos, en el sector posteroinferior izquierdo a la altura del conducto dentario inferior en zona molar. Al realizar la anamnesis la paciente refiere que durante estado de infección que había padecido días atrás, tenía parestesia de esa zona, con lo que determina que algo sucedía en relación al nervio dentario inferior. Se descarta sea un resto radicular de algunas de las extracciones dentarias anteriores por la ubicación en que se encuentra y por el tamaño y forma del objeto de estudio. Este se observa de mayor tamaño a lo que podía ser un resto radicular de una pieza dentaria aún en posición transversal.

Realizados todos lo estudios pertinentes se decide su tratamiento quirúrgica. Se presentan las fotos de lo distintos pasos operatorios.

Se decide realizar la enucleación de esa patología para lo que se emplea una incisión lineal sobre el reborde desdentado con des- inferior maxilla (Fig. 1). The patient reports having gone to an odontologist one month prior and that an intraoral radiography was taken and no visible pathology was found in the image given the absence of teeth.

A complete clinical study was carried out observing the absence of two inferior left molars. Good buccal dental health was observed. From there it was decided to take an external oral panoramic X-ray in order to more amply see the affected area (Fig. 2).

The $X$-ray showed a radiopaque image, circular in form with net margins at the left posteroinferior section at the height of the interior alveolar nerve in the molar zone. Upon carrying out the anamnesis the patient mentioned that during the period of infection that she endured in the days prior she had paresthesia in that area. With this we determine that something happened related to the inferior alveolar nerve. Because of its location, size and shape we dismiss the idea that it could be a radicular remnant of previous dental extractions. It is observed as being bigger than what could possibly be a radicular remnant of a tooth although its position is transversal.

Having carried out the pertaining studies we decided to surgically remove the tumor. The photos show the different surgical steps. 


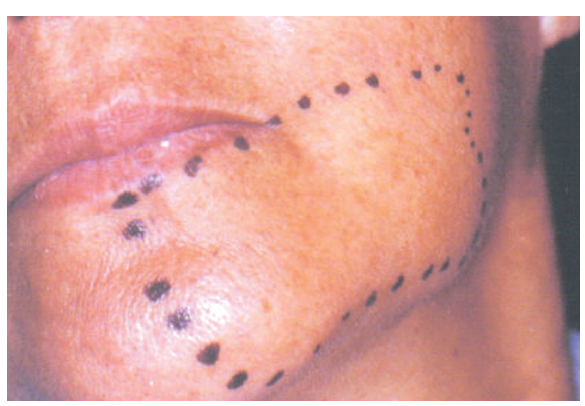

Figura 6. A los 15 días posteriores a la cirugía se marca la zona que el paciente identifica sin sensibilidad.

Figure 6. 15 days after surgery we mark the zone where the patient reports no sensitivity.

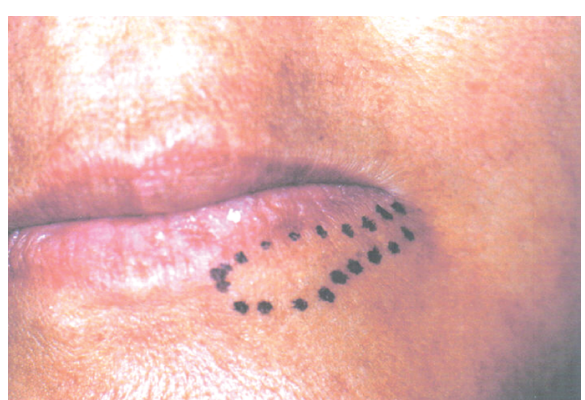

Figura 7. A los 3 meses posteriores a la cirugía disminuyó considerablemente la zona.

Figure 7. 3 months after surgery there is a considerable decrease in the size of this zone.

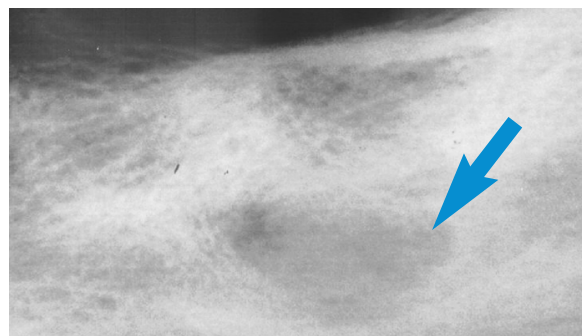

Figura 8. Imagen de una radiografía periapical en la zona del conducto dentario inferior realizada al año de la cirugía. El paciente recupero completamente la sensibilidad.

Figure 8. A periapical radiograph of the mandibular nerve region, one year after surgery. The patient showed a complete recovery of sensitivity. carga a nivel del 33, tras una osteotomía del la zona por donde se creía estaba la lesión, se encontró tejido de granulación dentro de una cavidad osteolítica. Se encuentra el nervio dentario inferior y a expensa de una delicada maniobra se lo levanta. Inmediatamente por detrás aparece una superficie sólida de tamaño pequeño que es retirada de una manera dificultosa ya que el espacio era muy pequeño y el objetivo era no lesionar el nervio dentario inferior, el que se reubica en su conducto. En la figura 3, se observa la cavidad remanente, surcado de izquierda a derecha por el paquete vasculonervioso. En la figura 4, se observa la sutura ya realizada y en la figura 5, el material extraído que fue enviado a realizar los estudios anatomopatológicos en la cátedra de Anatomía Patológica de la Facultad de Odontología de la Universidad de Buenos Aires.

Se observa en la figura 8 , una radiografía periapical de control tomada al año. En el lugar que ocupara el odontoma se observa un área con tendencia al aumento de densidad ósea y podemos ver el trayecto del conducto dentario a través de sus corticales superior e inferior. Clínicamente el paciente recuperó totalmente la sensibilidad.

El informe anatomopatológico nos informó que se encontró macroscópicamente un fragmento de tejido duro cilíndrico que mide $0,7 \times 0,4 \times 0,3 \mathrm{~cm}$ y tres fragmentos de tejido blando, blanco traslucido y que al corte no se encuentran particularidades. Microscópicamente esta constituido por fragmentos de tejidos dentarios, tejido óseo laminar esclerótico y reacción fibrogranulomatosa con infiltrado inflamatorio linfoplasmocitario. El diagnóstico corresponde a tejidos dentarios incluidos con reacción inflamatoria crónica, es decir que su diagnóstico es compatible con el de un odontoma.

\section{Discusión y conclusión}

Los tumores de origen odontogénico abarcan el $4 \%$ de todas las lesiones de la cavidad bucal y maxilares, los quistes suelen tener el $13 \%$ y el resto de las patologías abarcan el $83 \%$ restante según la bibliografía consultada (Tabla 1).

Se puede establecer que el odontoma es el tumor benigno odontológico más frecuente según el criterio de los distintos autores, con un alto predominio sobre los otros tumores. Estadísticamente, el odontoma complejo abarca el $37 \%$, el compuesto el $30 \%$ por enci-
We decided to carry out enucleation of the pathology, in which a linear incision is made over the toothless edge with a 3.3 level rush. Following osteotomy of the zone where the lesion was thought to be, we found granulation inside the osteolitic cavity. The inferior alveolar nerve was found and lifted using a delicate maneuver. Immediately behind it there is a small solid surface that is pulled back with difficulty given the small space and the objective not to harm the inferior alveolar nerve which is re-placed in its duct. In figure number 3 we observe the remaining cavity, grooved from left to right with a vascular nervous bundle. In figure \#4 we see the suture already carried out and in figure \# 5 we see the extracted material that was sent out for anatomicopatological studies in the Catedra de Anatomia Patologica de la Facultad de Odontologia de la Universidad de Buenos Aires.

In Figure 8 we observe periapical radiography of control taken after one year. When the odontoma is observed in an area that tends to increase in bone density through its superior and inferior corticals we can see a track of dental conduct. The patient fully recovered sensitivity.

The anatomicopatological report reports macroscopically finding a cyndrical piece of hard tissue measuring 0.7 $\times 0.4 \times 0.3 \mathrm{~cm}$ and 3 soft tissue fragments, white translucent, which when cut no abnormalities were found. Microscopically it is made up of dental tissue fragments, sclerotic bone tissue enamel and fibrogranulomatous reaction with infiltrated inflammatory limphoplasmocitary. The corresponding diagnosis of the dental tissues as well as chronic inflammatory extraction, this diagnosis is said to be compatible with that of odontoma.

\section{Discussion and Conclusion}

Tumors of odontogenic origin make up $4 \%$ of buccal cavity and maxilla lesions. The cysts usually make up 13\% and the remaining $83 \%$ are other pathologies, according to the literature consulted (Table 1).

According to the criteria of various authors, odontoma can be classified as the most frequent benign odontogenic 
ma del ameloblastoma que posee un $14 \%$ y el mixoma que se lo encuentra en un $7 \%$ (Tabla 2). $1,17-19$

La incidencia nos indica una predisposición del sexo masculino en un $60,5 \%$ por sobre el femenino $(39,5 \%)$ según la bibliografía consultada (Tabla 3) 1,2,20-22

El paciente tratado es del sexo femenino, en la sexta década de vida. La lesión se encontraba en el maxilar inferior en la zona posterior del lado izquierdo no coincidiendo con la prevalencia tanto en edad, sexo y ubicación la lesión según la bibliografía consultada., 23-28

Quedo corroborado que la técnica panorámica es el estudio radiográfico convencional adecuado para poder diagnosticar este tipo de afecciones por la visualización completa de los maxilares y estructuras limítrofes como por su baja exposición gonodal. ${ }^{29}$

De lo expuesto se demuestra la importancia de poder solicitar el estudio radiográfico adecuado para poder obtener un diagnóstico presuntivo correcto ya sea por ubicación, forma y tamaño de la lesión. El cumplimiento estricto de las normas de bioseguridad y el seguimiento correcto de los pasos operatorios en el tratamiento quirúrgico para evitar las posibles complicaciones posteriores a la cirugía. La corroboración a través de los estudios histopatológicos es imprescindible para la resolución del caso y seguimiento a través de controles radiográficos a corto, mediano y largo plazo.

\section{Bibliografía}

1. Kramer IRH, Pindborg J], Shear M. Histological typing of odontogenic tumours. WHO International histological classification of tumours. Berlin: Springer-Verlag; 1992. p. 21.

2. Philipsen HP, Reichart PA, Praetorius F. Mixed odontogenic tumours and odontomas. Considerations on interrelationship. Review of the literature and presentation of 134 new cases of odontomas. Oral Oncol 1997;33:86-99.

3. Daley TD, Wysoki GP, Pringle GA. Relative incidence of odontogenic tumors and oral jaw cyst in a canadian population. Oral Surg Oral Med Oral Pathol 1994;77:276-80.

4. Hisatomi M, Asaumi II, Konouchi H, Honda Y, Wakasa T, Kishi K. A case of complex odontoma associated with an impacted lower deciduous second molar and analysis of the 107 odontomas. Oral Dis 2002;8:100-5.

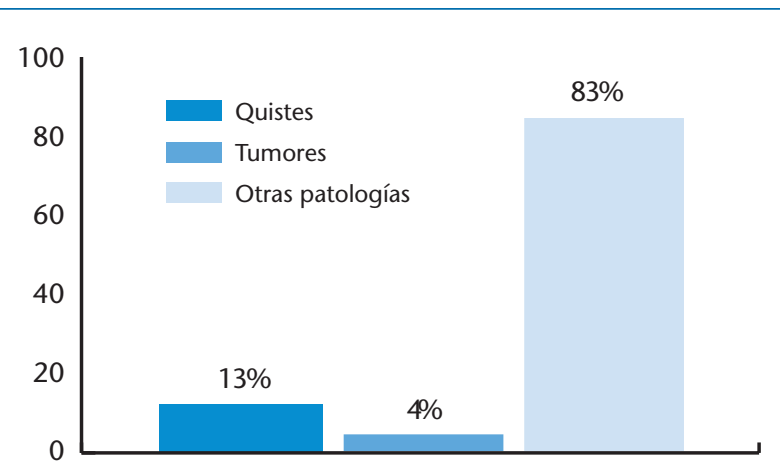

Tabla 1. Porcentaje de lesiones en cavidad bucal y maxilares. Table 1. Percentage of lesions in the buccal cavity and maxillas.

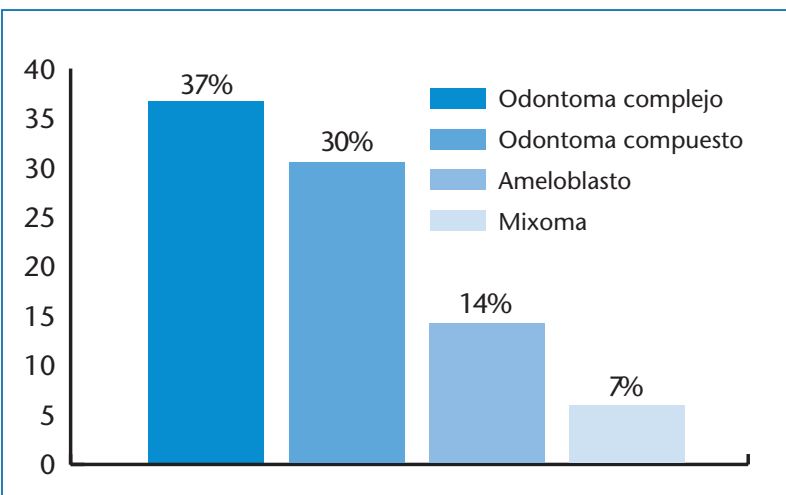

Tabla 2. Frecuencia de los tumores odontogénicos benignos. Table 2. Frequency of benign odontogenic tumors.

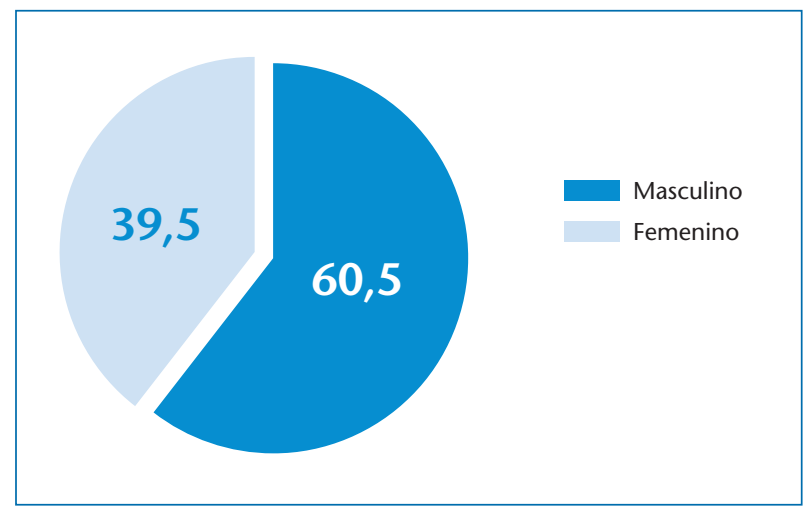

Tabla 3. Incidencia según sexos.

Table 3. Incidence according to sex. tumor. It is more predominant than other tumors. Complex odontoma is found in $37 \%$ of cases, Compound odontoma is found in $30 \%$ of cases, and ameloblastoma in $14 \%$ and myxoma in $7 \%$ of cases (Table 2). 1,17-19

According to the biography consulted men are predisposed. The percentages are the following: Male $60.5 \%$ Female $39.5 \%$. 11,2,20-22 $^{1,2}$

The patient treated in this study is female in her sixties. The lesion was found in the inferior maxilla in the left posterior zone. According to the biography, because of the location of the lesion, and the sex and age of the patient this case does not correspond to typical cases. 1,23-28

I remain certain that the panoramic technique is the conventionally appropriate radiographic study in order to be able to diagnose these types of affections with complete visibility of the maxillas and bordering structures because of its low gonodal exposure. ${ }^{29}$

From what we have seen it shows the importance of being able to solicit an appropriate radiographical study to be able to obtain a presumably correct diagnosis based on location, shape and size of the lesion. Carrying out the strict guidelines of biosecurity and proper implementation of the operative steps in surgical treatment are vital to avoiding possible complications after surgery. Using Histopathological studies is essential to resolving the case and follow-up using radio graphic controls over the short and long term. 
5. Swan RH. Odontomas. A review, case presentation and periodontal considerations in treatment. J Periodontol 1987;58:856-60.

6. Ide F, Shimoyama T, Horie N. Gingival peripheral odontoma in an adult: case report. J Periodontol 2000;71:830-2.

7. Rumel A, de Freitas A, Birman EG, Tannous LA, Chacon PT, Borkas S. Erupted complex odontoma. Report of a case. Dentomaxillofac Radiol 1980; 9:5-9.

8. Al-Sahhar WF, Putrus ST. Erupted odontoma. Oral Surg Oral Med Oral Pathol 1985;59:225-6.

9. Serio FG, Levy BA. Erupted compound odontoma. Review and report of case. Ann Dent 1987;46:41-2.

10. Gomel M, Seçkin T. An erupted odontoma: case report. J Oral MaxiIlofac Surg 1989;47:999-1000.

11. López-Areal L, Silvestre Donat F, Gil Lozano J. Compound odontoma erupting in the mouth: 4-year follow-up of a clinical case. / Oral Pathol Med 1992;21:285-8.

12. Kaneko M, Fukuda M, Sano T, Ohnishi T, Hosokawa Y. Microradiographic and microscopic investigation of a rare case of complex odontoma. Oral Surg Oral Med Oral Pathol Oral Radiol Endod 1998;85:1314.

13. Ferrer MJ, Silvestre FJ, Estrelles E, Grau D, López R. Recurrent infection of a complex odontoma following eruption in the mouth. Med Oral 2001;6: 269-5.

14. Ragalli CC, Ferreria JL, Blasco L. Large erupting complex odontoma. Int J Oral Maxillofac Surg 2000;29:373-4.

15. Amado S, Gargallo J, Berini L, Gay C. Revisión de 61 casos de odontoma. Presentación de un odontoma complejo erupcionado. Med Oral 2003;8:366-73.

16. López-Areal L, Silvestre Donat F, Gil Lozano J. Compound odontoma erupting in the mouth: 4-year follow up of a clinical case. J Oral Pathol Med. 1992;21:285.

17. Cataldo E, Santis HR. A clinico-pathologic presentation. Ameloblastic fibrous odontoma. J Mass Dent Soc. 1992;41:43.
18. Piattelli A, Trisi P. Ghost cells in compoun odontoma: a study of undemineralized material. Bull Groyp Int Rech Sci Stomatol Odontol. 1991;34:145.

19. Owens BM, Schuman NJ, Mincer HH. Dental odontomas: a retrospective study of 104 cases. J Clin Pediatr Dent. 1997;21:261.

20. De Alesio D, Creosinin ML. Odontoma compuesto complejo: un caso clinico. Rev Asoc Odontol Argent 2003; 91:433-6. 21. Ragalli CC, Ferreria JL, Blasco L. Large erupting complex odontoma. Int J Oral Maxillofac Surg 2000;29:373-4.

22. Amado S, Gargallo J, Berini L, Gay C. Revisión de 61 casos de odontoma. Presentación de un odontoma complejo erupcionado. Med Oral 2003;8:366-73

23. Dinatale E. Neuralgia sintomática de la tercera rama del trigémino asociada a un odontoma compuesto. Presentación de un caso. Acta Odontol Venez 2003; 41:50-3.

24. Ferrer MJ, Silvestre FJ, Estrelles E, Grau D, López R. Recurrent infection of a complex odontoma following eruption in the mouth. Med Oral 2001;6:269-5.

25. Hisatomi M, Asaumi JI, Konouchi H, Honda Y, Wakasa T, Kishi K. A case of complex odontoma associated with an impacted lower deciduous second molar and analysis of the 107 odontomas. Oral Dis 2002;8:100-5.

26. De Oliveira BH, Campos V, Marcol S. Compound Odontoma- diagnosis and treatment: Three cases report. Pediatr Dent 2001;23:151-7.

27. Nelson P, Silva A, Farias G, Freitas AC. Odontoma-hice malformation on in a permanent maxillary central incisor subsegment to trauma to the incisor predecesor. Dent Traumatol 2005;21:309-12.

28. Bantra P, Dugal R, Kharbanda OP, Porkous H. Odontogenic treatment of impacted anterior teeth due to odontomas a report of two cases. J Clin Pediatric Dental 2004;28:289-94.

29. Rushton VE, Horner K. The use of panoramic radiology in dental practice. J Dent. 1996;24:185-201. 